\title{
THE EFFECT OF INTERNAL AND EXTERNAL ACCOUNTABILITY, JOB MOTIVATION AND EDUCATION ON LOCAL GOVERNMENT OFFICIAL'S PERFORMANCE
}

\author{
Kathleen Asyera Risakotta \\ Faculty of Economics and Business, Universitas Pattimura, Indonesia \\ (kathleenasyerarisakotta23@gmail.com) \\ Rusdi Akbar \\ Faculty of Economics and Business, Universitas Gadjah Mada, Indonesia \\ (rusdi.akbar@ugm.ac.id)
}

\begin{abstract}
This study aims to empirically analyze the influence of internal and external accountabilities, job motivation and education on the performance of local government officials with organizational commitment as the intervening variable. This study used a mixed method that consists of a Partial Least Square (PLS) for the analysis of the quantitative and thematic content analysis for the qualitative approach. The sample includes 224 government officers from the Provincial Government of Maluku Province and Ambon City Council. The result of this study shows that internal accountability, job motivation, and organizational commitment have a positive influence on the performance of the local government employees, while both external accountability and education do not play a positive role in their organizational commitment. These are the driving factor for organizations to improve the accountability and performance of government institutions so that good governance may occur in the future. The results of this study could be used as advice to local governments on their employee training programs in order to improve the performance of the employees of local government agencies.
\end{abstract}

Keywords: internal accountability, external accountability, job motivation, education, organizational commitment, performance, institutional theory, mixed method.

JEL Classification: M48 


\section{INTRODUCTION}

In public sector organizations, public sector management reformation is known as the concept of New Public Management (NPM). NPM focuses on results, outcomes, and accountability results (Hood, 1991). According to Hood (1991), there are seven characteristics of NPM, including (1) the implementation of government management tasks being handed over to professional managers, (2) the standards and performance measures are clear, (3) more emphasis placed on the control results, (4) the division of tasks within the units, (5) growing atmosphere of competition in the body of public sector organizations, (6) an emphasis on the application of private sector management styles, and (7) a greater emphasis on high discipline and not wasting the limited resources. These characteristics can be seen as an effort to improve the management of public sector organizations and thus improve their services to the public.

According to Akbar et al. (2012), it has been revealed that implementation of NPM could increase government accountability and transparency so that the necessary information is more relevant in order to assess performance. There is the issue of the Presidential Instruction Number 7 of 1999 on Accountability Reporting of the Performance of Government Institutions (Instruksi Presiden Nomor 7 Tahun 1999, tentang Akuntabilitas Kinerja Instansi Pemerintah). The Presidential Instruction requires all government institutions to report their performance to the central government. This is supported by the issuance of the Head of the Institute of Public Administration's decision, Number 239 / IX / 6/8/2003 on Guidelines for the Preparation of Reporting Accountability of Government Performance, which was intended to be a response to the need for good governance at all levels of government (Keputusan Kepala
Lembaga Administrasi Negara (LAN) Nomor 239/IX/6/8/2003 tentang Pedoman Penyusunan Pelaporan Akuntabilitas Kinerja Instansi Pemerintah). The existence of these orders causes every government institution to have to prepare and report their performance, to reform the management of public sector organizations. It suggests that the performance of government institutions at the most basic level needs to be considered, for the implementation of good governance.

Accountability is considered to be an important element for any government institution, as it improves its performance. However, Akbar et al. (2012) state that the factors leading to local governments implementing accountability are their obligation to do so under the current legislation and intense pressure from the central government. Accountability in Maluku's Provincial Government, as the object of this research, is an unfinished phenomenon for the institutions in it. This may be due to a tendency for the Provincial Government of Maluku to only report on the programs it has successfully achieved, compared to those programs that fail (Nurkhamid, 2008). Performance reports submitted in the form of Accountability Reports of Governmental Institutions (LAKIP) have been biased (Nurkhamid, 2008). The bias arose because the performances delivered did not equate with the realities, so that they mislead the public as the users of information, ultimately resulting in the public's excessive expectations of the government agencies (Ahyaruddin, 2016).

Robbins (2010) revealed that the organization is a social entity that coordinates consciously and works continually, in order to achieve a common goal. Because the organization is supported by a group of people or individuals, the organization's success and performance depend on these individuals. The role of individual characteristics, such as 
motivation, educational background, and commitment can improve their performance. Motivation is a desire in a person that causes the person to act in order to achieve certain goals (Mathis \& Jackson, 2006). Motivated employees will work hard at their activities and thus will achieve their goals. The motivation of the employees will increase their organizational commitment since employees will feel a sense of belonging to the organization where they work. The second is education; employees who have a better education will be able to increase their commitment and demonstrate better performance. The primary function of government is to serve the interests of the public so that the government seeks to improve the quality of their service performance. Due to the given commitment, the expected performance of the employees will be increased, because the organization's commitment is an attitude that reflects the employees' loyalty to the organization, and is a continuous process in which they have expressed concerns about the organization (Nugraha, 2013). Each employee who has a strong commitment will provide the best performance they can for the country, and offer the best service to the public, so the performance of the public sector will increase (Nugraha, 2013). Organizational commitment is an essential component of the performance.

This research specifically focuses on internal and external accountability, job motivation, education, organizational commitment, and performance. It also investigates whether institutional isomorphism occurs in the accountability of public sector organizations. This research is based on the institutional theory, as one of the theories that are appropriate to explain that the changes in public sector organizations are heavily influenced by their external environment and the need to gain legitimacy and political support (Ashworth et al., 2007). According to the background described previously, the research question is whether internal accountability, external accountability, job motivation, and education have a positive influence on organizational commitment. Does organizational commitment have a positive effect on performance? Does institutional isomorphism occur in the practice of accountability in local government agencies?

This study uses the Structural Equation Modelling - Partial Least Square (SEM-PLS) approach to analyze and test the research model. The results of the study were found by conducting surveys and interviews with local government working units (SKPD), which found evidence that internal accountability, job motivation, and organizational commitment have a positive influence on the performance of the local government employees, while both external accountability and education do not play a positive role in their organizational commitment. The results of hypotheses' testing are corroborated by the result from in-depth interviews, especially for institutional isomorphism in the practices of local government.

This study also contributes to the public sector organizations, especially the government agencies in the local government of Maluku, to urge them to give greater attention to the accountability, organizational commitment, job motivation, and educational background of their staff, since all of these factors can provide a contribution to the improvement of performance. Overall this paper is organized as follows: the first section of this paper describes the problem and the context of the overall study which were discussed in the introduction. Then the next section discusses the literature review and hypotheses development, the research methods, and the results of the study and their discussion. The final section of this paper presents the conclusions, implications, the limitations of the study and suggestions for further research. 


\section{LITERATURE REVIEW}

\section{Institutional Theory}

The institutional theory is a sociological theory that seeks to explain the structure of organizations (Scott, 1995). The institutional theory describes a structure in which an organization adopts something by the commonly held norms, which then leads to a culture of legitimacy and support from external organizations. DiMaggio and Powell (1983) suggested that, from time to time, in an area that is well established, the organization tends to move toward homogenization, although at first, they may show a sizable diversity. The appropriate term to describe the process of homogenization is an isomorphism. DiMaggio and Powell (1983) distinguished two types of isomorphism: competitive isomorphism and institutional isomorphism.

This study adopts the form of institutional isomorphism as conformity within the public sector environment, which is not involved in open competition nor the conditions in which the organization must attempt for political power and institutional legitimacy. Institutional isomorphism describes the process of the homogenization of an organization. Therefore, the isomorphism is defined as the process that forces one unit in a population to resemble other units that face the same environmental conditions (DiMaggio \& Powell, 1983).

Three isomorphisms distinguished by DiMaggio and Powell (1983) are those which coercive or are mimetic, or normative. First, a coercive isomorphism comes from political influence and legitimacy problems. The pressure comes from formal or informal pressure from other organizations, where they are interdependent. Second, a mimetic isomorphism emerges as a result of the process to respond to the uncertainty of the environment, in the area where the organization operates. When there is uncertainty, organizations tend to imitate others, in order to achieve legitimacy. Third, the normative isomorphism is related to professionalism and a way of formal or informal collaboration that could lead to the homogenization of the organization (Akbar et al., 2012).

\section{Performance}

The performance consists of three elements, including (1) goal setting that serves to improve the performance in the context of setting and culture, (2) measuring serves to realize the goals in the form of achievement, while (3) assessment is used to assess the performance (Cascio, 1998a). According to Flippo (1984), there are standard measures for individual performance, including: (1) the quality of the work, including its timeliness, accuracy and neatness, (2) the quantity of work, including the number of regular jobs and the amount of additional work, (3) toughness at work, including following instructions, safety at work, and having initiative and presence, (4) the correct attitude, including having responsibility for the work and offering cooperation.

\section{Accountability}

Accountability is defined as a form of obligation to account for the success, or failure, of the implementation of the organization's mission in achieving the goals and objectives that have been set previously, through periodical accountability reporting (Stanbury, 2003). Roberts and Scapens (1985), quoted by Sinclair (1995) said that accountability requires a relationship where someone is asked to explain and take responsibility for their actions.

In the system of constitutional government, there are two types of accountability: (1) internal accountability, which is a type of direct 
accountability that applies in a particular organization, where the system involves direct reporting by subordinates to their superiors who hold power, (2) external accountability, which is an indirect type of accountability that involves reporting to parties outside the organization (Akbar, 2011). In this study, researchers refer to the two types of accountability, namely internal and external. These categories are said to be well suited to the conditions of decentralized government organizations in Indonesia (Akbar et al., 2012).

Internal and external accountability reflect the coercive isomorphism that occurs because of compliance with the regulations and legislation, for example with the issuance of the Presidential Instruction Number 7 of 1999 on the Accountability Reporting of the Performance of Governments Institutions (Instruksi Presiden Nomor 7 Tahun 1999, tentang Akuntabilitas Kinerja Instansi Pemerintah).

Related studies found that managements' commitment to having a positive relationship with internal accountability and external accountability (Akbar et al. 2012) could be measured by using instruments that measure a person's perception of the organizational commitment of his/her superiors. Based on the description above, the following hypotheses can be formulated:

H1: Internal accountability has a positive influence on organizational commitment.

H2: External accountability has a positive influence on organizational commitment.

\section{Job Motivation}

Job motivation (As'ad, 2008) is a construct that measures employees' spirit and willingness to work, which aids their advancement and development within the organization. The employees carry out their specific duties based on their motivation. In this study, researchers used the theory of McClelland's need for achievement (achievement theory), which focuses on three needs, (1) the need for attainment, which explains that every individual has a strong drive to succeed, (2) the power requirement is the desire of individuals to have an influence, be influential and to control other individuals, (3) the need for relationships so that individuals can acquire good social relations in their work environment.

Banget al., (2013) and Purnamaet al.,(2016) reported that motivation has a positive influence on organizational commitment. Based on these descriptions, a third hypothesis is formulated as follows:

H3: Work motivation has a positive influence on organizational commitment.

\section{Education}

Knowledge is a characteristic acquired by learning, which leads to a focus on one particular concept to establish competency in a person so that the success of an assignment will be influenced by the knowledge or competence of the person who performs the task (Sofyani \& Akbar, 2015).

Research conducted by Wang et al., (2015) and Akinyemi (2014) found that education positively affects organizational commitment. Thus, individuals who have received a suitable education, that prepares them for their duties, will be more committed to the organization and less likely to leave the organization and be motivated to prove themselves by being able to show better performance. Based on the description above, a fourth hypothesis is formulated as follows:

H4: Education has a positive influence on organizational commitment. 


\section{Organizational Commitment}

Allen and Meyer (1990) define commitment as a psychological condition which characterizes the relationship between the employee and the organization, which has implications in any decision to continue the working relationship with the organization or not. Allen and Meyer (1997) distinguish organizational commitment into three components: affective commitment, normative commitment, and a commitment continuant.

First, affective commitment means a person's emotional involvement with their organization, in the form of feelings of love toward his/her organization. Affective commitment is in the form of a positive interaction between the employees and the company, because of the similarity value (Cetin, 2006). Second, normative commitment means a moral dimension that is based on feelings of obligation and responsibility to the organization that hired him/her (Hartman, 2000). Third, a continuant commitment is defined as a person's perception of the costs and risks when leaving an organization. According to Clugston, (2000) a commitment continuant is an employee who wishes to remain a part of the organization where he/she currently works.
Research conducted by Camilleri (2007) and Sholihin and Pike (2009) suggests that organizational commitment positively affects performance. Based on the description above, the fifth hypothesis is formulated as follows:

H5: Organizational commitment has a positive effect on performance.

\section{DATA, METHOD AND ANALYSIS}

\section{Population and Sample}

This research was conducted on the local government staff of Maluku, which includes those of the Government of Maluku Province. The object of this research was the employees in the local government agencies. The method used for selecting the sample was purposive sampling; the samples were chosen based on specific criteria. The criteria used was for individual samples, with the employee being, at minimum, an echelon IV employee in each department, who has been involved in the process of accountability and has held a position of responsibility for at least one year, so that the respondent is believed to have an understanding of the conditions in these institutions (Nurkhamid, 2008).

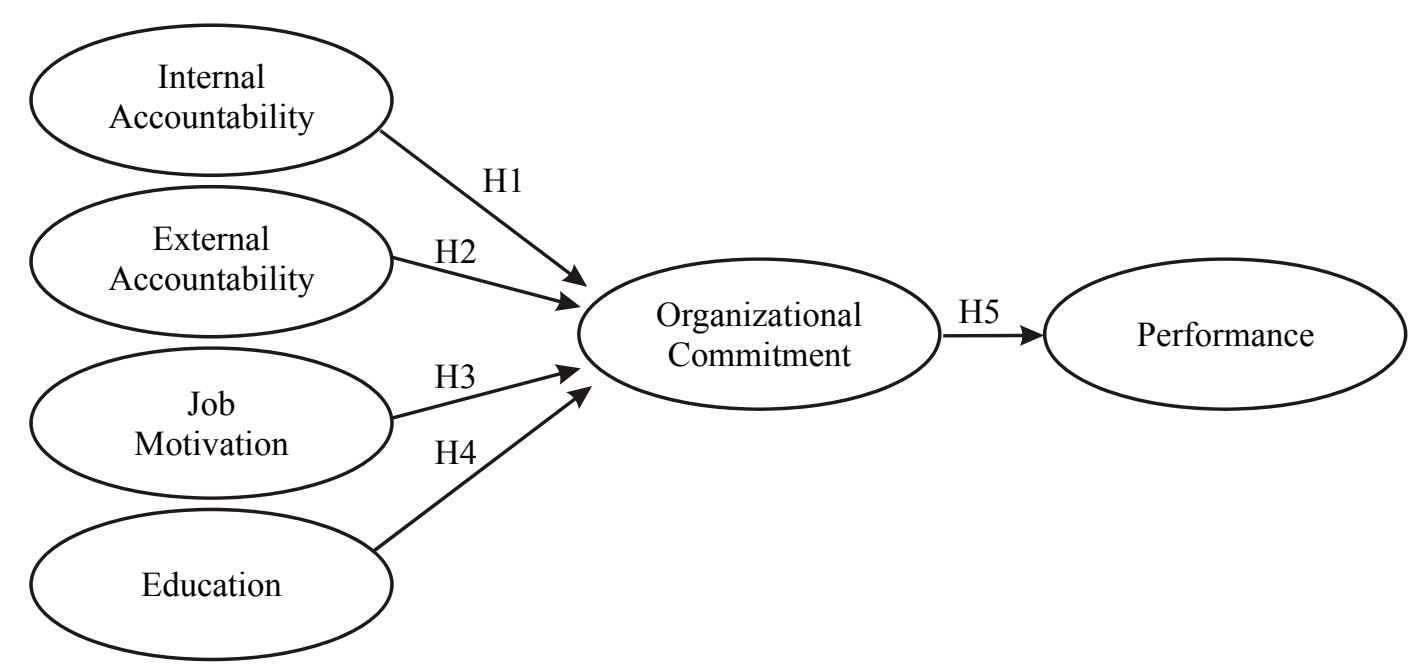

Figure 1. Research Model 


\section{Research Design and Data Collection Techniques}

This study uses a mixture (mixed method) with a sequential explanatory design, which allows researchers to collect data through two phases: quantitative and qualitative (Creswell \& Clark, 2011). The need to use this mixed method to solve a research problem is because it is not enough to only rely on one data source. In addition, any preliminary findings from the results of the statistical tests need an in-depth explanation, available through a qualitative approach (Creswell \& Clark, 2011).

The first stage involves the collection of data by using a questionnaire survey and an analysis of the quantitative data. Then, based on the quantitative results, the second phase of data collection involves interviews and then analyzing the qualitative data with the aim of explaining the findings/results of the quantitative phase.

\section{Measurement Variable}

\subsection{Performance}

This variable is an endogenous variable. Performance variables in this study were measured by using an instrument of Spekle and Verbeeten (2014). The instrument is specifically designed to measure performance in public sector organizations. The dimensions of performance include productivity, quality or accuracy of the work produced, the amount of innovation, process improvement or new ideas, a reputation for excellence of work, achievement of production or service level objectives, operating efficiency, and the spirit of the unit's personnel. Respondents, in this case, were asked to indicate the scores for their organizational units for each of these performance dimensions, by assigning points in a Likert scale of one to five (one = well below average, five $=$ far above average) .

\subsection{Accountability}

This variable is an exogenous variable. Researchers used two concepts of accountability that are used in the research by Akbar et al. (2012), namely internal accountability and external accountability. Internal accountability is a type of direct accountability that applies to a particular organization, and the system involves direct reporting by subordinates to superiors who hold power. External accountability is an indirect type of accountability that involves reporting to parties outside the organization (Matek, 1977 as cited by Akbar, 2011). The instrument used was adopted from Cavaluzzo and Ittner (2004), Akbar et al. (2012) and Wang (2002) with some adjustments based on the context of Indonesia by using a Likert scale of one to five (one $=$ strongly disagree, five $=$ strongly agree).

\subsection{Job motivation}

Job motivation is an exogenous variable. This variable was measured through the McClelland theory that focuses on three needs, namely, (1) the needs of attainment, which explains that every individual has a strong drive to succeed; (2) the power requirement is the desire of individuals to have an influence, be influential and to control other individuals; and (3) the needs of the relationship, in that individuals seek to acquire good social relations in work environment. This instrument was adopted from Hanif (2014) by using a Likert scale from one to five (one=strongly disagree, five $=$ strongly agree).

\subsection{Education}

Education is an exogenous variable. This variable describes the level of education of the individual is measured by looking at the education level of the respondents, (1) high school, (2) bachelor's degree, (3) master's degree. 


\subsection{Organizational Commitment}

Organizational commitment is an exogenous variable. Organizational commitment is defined as a desire that arises due to feelings of affection toward an organization, feelings of mandatory (normative) and cost concerns or the risk of losing one's job (continuant). Employees with high levels of effective organizational commitment have feelings of love for the organization where they work. Normative implies a moral dimension that is based on the feelings of obligation and responsibility to the organization where the person works. Continuant is defined as a person's perception of the costs and risks if he/she should leave the organization. This variable was measured using an instrument adapted from Allen and Meyer (1997) by using a Likert scale of one to five (one = strongly disagree, five $=$ strongly agree). The higher the number chosen, the better the organizational commitment of the employee.

\section{Data Analysis Method}

The collection of quantitative data in the first stage of this research was through a survey. To analyze the quantitative data, our hypotheses testing were done using Structural Equation Modelling - Partial Least Square (SEM-PLS) using software SMARTPLS 2.0. In the second phase, the qualitative data's collection used thematic content analysis. SEM-PLS was used because it was able to test several dependent and independent variables simultaneously (Gudono, 2012; Akbar, 2011; Barclay et al., 1995).

\section{RESULT AND DISCUSSION}

\section{Quantitative Analysis}

\subsection{Pilot Study}

Respondents to the pilot study were 30 students working in government agencies who are currently studying for their Master of Development Economics (MEP) and Master of Accounting at the Faculty of Economics and Business Universitas Gadjah Mada. These respondents were chosen because they have characteristics that are similar to the actual respondents who will be the target of the research sample.

Data from the test results were analyzed using the SmartPLS software. The results of these tests show that the construct validity of the research is quite good. This can be seen from the loading factor values for the items used to measure the construct, which met the minimum standard (loading $>0.70$ ). Furthermore, the composite reliability's test results had a Cronbach's alpha score above 0.60 .

The results of the tests performed show that internal accountability and work motivation have no effect on organizational commitment, but external accountability influences performance. Furthermore, organizational commitment also influences performance. Overall, the trial results of this instrument did not undergo any significant changes and were suitable for use in the study.

\subsection{Quantitative Data Collection}

A survey, in the form of questionnaires to the staff of each local government department in Maluku is used to collect the qualitative data. We distributed 263 questionnaires, 234 were returned, of which ten were incomplete and could not be used to analyze the data, and so were removed from the sample, leaving us with 224 questionnaires that could be used, giving a response rate of $85.2 \%$ (see Table 2). Information about the profiles of the respondents can be seen in Table 1 . 
Table 1. Profile of Respondents

\begin{tabular}{|c|c|c|}
\hline Description & $\begin{array}{l}\text { Number } \\
\text { (People) }\end{array}$ & $\begin{array}{c}\text { Percentage } \\
\text { (\%) }\end{array}$ \\
\hline \multicolumn{3}{|l|}{ Gender: } \\
\hline Male & 115 & $51.3 \%$ \\
\hline Female & 109 & $48.7 \%$ \\
\hline Total & 224 & $100 \%$ \\
\hline \multicolumn{3}{|l|}{ Age: } \\
\hline$<30$ years old & 9 & $4 \%$ \\
\hline $31-40$ years old & 28 & $12.5 \%$ \\
\hline $41-50$ years old & 109 & $48.7 \%$ \\
\hline$>50$ years old & 78 & $34.8 \%$ \\
\hline Total & 224 & $100 \%$ \\
\hline \multicolumn{3}{|l|}{ Education: } \\
\hline High School & 17 & $7.6 \%$ \\
\hline Bachelor's Degree & 143 & $63.8 \%$ \\
\hline Master's Degree & 64 & $28.6 \%$ \\
\hline Total & 224 & $100 \%$ \\
\hline \multicolumn{3}{|l|}{ Length of service : } \\
\hline$>10$ years & 13 & $5.8 \%$ \\
\hline $10.1-20$ years & 127 & $56.7 \%$ \\
\hline$>20$ years & 84 & $37.5 \%$ \\
\hline Total & 224 & $100 \%$ \\
\hline \multicolumn{3}{|l|}{ Echelon: } \\
\hline IV & 138 & $61.6 \%$ \\
\hline III & 62 & $27.7 \%$ \\
\hline II & 4 & $1.8 \%$ \\
\hline Others & 20 & $8.9 \%$ \\
\hline Total & 224 & $100 \%$ \\
\hline
\end{tabular}

Table 2. Questionnaires' Distribution and Response Rate

\begin{tabular}{|c|c|c|c|c|c|c|}
\hline Description & Distributed & Returned & Response Rate & In-complete & Used & Response Rate Used \\
\hline $\begin{array}{l}\text { Maluku } \\
\text { Province }\end{array}$ & 131 & 111 & $47.4 \%$ & 6 & 105 & $46.8 \%$ \\
\hline $\begin{array}{l}\text { Ambon } \\
\text { City }\end{array}$ & 132 & 123 & $52.6 \%$ & 4 & 119 & $53.2 \%$ \\
\hline Total & 263 & 234 & $100 \%$ & 10 & 224 & $100 \%$ \\
\hline
\end{tabular}

Source: Primary Data, analyzed

\subsection{Non-response bias}

This research does not respond to any test bias due to location, because of the extensive research area, which includes two regions. A
Kruskal-Wallis test was carried out to make sure that there were not any inter-regional differences, including a non-parametric test to simultaneously compare the two data groups 
(Supangat, 2007) with SPSS 19.0. The results show that there are no inter-regional differences in the samples of the study. The Kruskal-Wallis test gives the following results for each area: Maluku Province $(\mathrm{n}=105)$ and Ambon City $(n=119)$ at a significance of $>0.05$, while for the constructs the results are: internal accountability construct $\quad(\mathrm{t}=0.637)$, external accountability construct $(\mathrm{t}=0.768)$, job motivation construct $(\mathrm{t}=0.914)$, organizational commitment construct $(t=0.770)$, performance construct $(t=0.728)$.

\subsection{Hypotheses Testing}

Based on the results of the measurement model analysis (path analysis) using iterative algorithms, PLS displays the validity and reliability of the test results. The validity test, consisting of the convergent validity through AVE scores and commonality criteria, was > 0.5 , but a score of 0.4 was given a tolerance (Lai and Fan, 2008; Vinzi et al., 2010) and discriminant validity through a balanced cross loading criteria $>0.6$. Furthermore, the reliability test scores seen for the composite reliability criteria were $>0.6$.

Table 4 shows that the instrument can be declared valid and reliable because it has met the criteria for validity and reliability. Structural models were evaluated using $\mathrm{R}^{2}$. Table 4 shows the value of $R^{2}$ for the construct of organizational commitment is at 0.1309 and 0.0781 for the construct of performance, while the remainder is explained by other variables outside the proposed model.

Table 3. Kruskal Wallis Test

\begin{tabular}{clccc}
\hline & Research Location & N & Mean & T-Statistic \\
\hline $\begin{array}{c}\text { Internal } \\
\text { Accountability }\end{array}$ & Maluku Province & 105 & 114.62 & 0.637 \\
& Ambon City & 119 & 110.63 & \\
\hline Total & 224 & & \\
Eccountability & Ambon City & 105 & 111.18 & 0.768 \\
& Total & 224 & 113.66 & \\
\hline Job & Maluku Province & 105 & 113.00 & 0.914 \\
Motivation & Ambon City & 119 & 112.06 & \\
\hline Total & 224 & & \\
\hline Organizational & Maluku Province & 105 & 113.83 & 0.770 \\
Commitment & Ambon City & 119 & 111.33 & \\
\hline & Total & 224 & & \\
\hline Performance & Maluku Province & 105 & 110.91 & 0 po.728 \\
& Ambon City & 119 & 113.90 & \\
\hline & Total & 224 & & \\
\hline
\end{tabular}

Source: Primary Data, analyzed 
Table 4. Overview Iteration Algorithm PLS

\begin{tabular}{lccccc}
\hline & AVE & Composite Reliability & R Square & Cronbach's Alpha & Communality \\
\hline Internal Accountability & 0.5733 & 0.8428 & 0.0000 & 0.7523 & 0.5733 \\
External Accountability & 0.6481 & 0.9362 & 0.0000 & 0.9218 & 0.6481 \\
Job Motivation & 0.4205 & 0.8662 & 0.0000 & 0.8384 & 0.4205 \\
Education & 1.0000 & 1.0000 & 0.0000 & 1.0000 & 1.0000 \\
Organizational Commitment & 0.4856 & 0.8240 & 0.1309 & 0.7375 & 0.4856 \\
Performance & 0.6758 & 0.9357 & 0.0781 & 0.9201 & 0.6758 \\
\hline
\end{tabular}

Source: Primary Data, analyzed

All hypotheses testing were conducted through the structural model test by comparing the $\mathrm{T}$-statistic value and $\mathrm{T}$-table value. The results of the test with bootstrapping, as summarized in Table 4, show that the internal accountability hypothesis (H1) is supported (internal accountability and organizational commitment: $(\gamma 1=0.2416, \mathrm{t}=3.3136)$. The job motivation hypothesis (H3) is supported (job motivation and organizational commitment: $(\gamma 1=0.1882, \quad t=2.6478)$. This hypothesis is supported by the value of $(\mathrm{t}>1.64 ; \mathrm{P}<0.05)$ and $(\mathrm{t}>2.33 ; \mathrm{P}<0.01) \quad$ (one-tailed). $\mathrm{H} 2 \quad$ (external accountability and organizational commitment: $\gamma 1=-0.0395, \mathrm{t}=0.4870)$ is not supported because the value of the T-statistic is lower than the value of the T-table (1.64), $\mathrm{H} 4$ (education and organizational commitment: $\quad \gamma 1=0.0750$, $\mathrm{t}=1.1003)$ is also not supported due to the same reason. Further, H5 shows organizational commitment has a positive effect on performance $(\gamma 1=0.2794, \mathrm{t}=4.4043)$. Overall results of the hypotheses' testing are presented in Table 5.

\section{Qualitative Analysis}

\subsection{Qualitative Data Collection}

The selection of respondents for the interview was conducted from the results of the quantitative data's processing and some further criteria, such as only selecting the outlier respondents, the availability of these respondents to be interviewed, and the representation of the area of study that was expected to represent the population. Figure 2 shows the distribution of the data's processing; the quantitative data show the outliers by using an analysis of the scatter plot.

Table 5. Path Coefficient (Mean, STDEV, T-Values)

\begin{tabular}{|c|c|c|c|c|c|}
\hline & $\begin{array}{c}\text { Original } \\
\text { Sample }\end{array}$ & $\begin{array}{c}\text { Sample } \\
\text { Mean }\end{array}$ & St. Deviation & St. Error & T-Statistics \\
\hline \multicolumn{6}{|l|}{ Internal Accountability- } \\
\hline$>$ Organizational Commitment & 0.2416 & 0.2423 & 0.0729 & 0.0729 & 3.3136 \\
\hline \multicolumn{6}{|l|}{ External Accountability - } \\
\hline$>$ Organizational Commitment & -0.0395 & -0.0306 & 0.0812 & 0.0812 & 0.4870 \\
\hline \multicolumn{6}{|l|}{ Job Motivation $->$ Organizational } \\
\hline Commitment & 0.1882 & 0.3187 & 0.0711 & 0.0711 & 2.6478 \\
\hline \multicolumn{6}{|l|}{ Education->Organizational } \\
\hline Commitment & 0.0750 & 0.0492 & 0.0681 & 0.0681 & 1.1003 \\
\hline \multicolumn{6}{|l|}{ Organizational Commitment - } \\
\hline$>$ Performance & 0.2794 & 0.3367 & 0.0634 & 0.0634 & 4.4043 \\
\hline
\end{tabular}




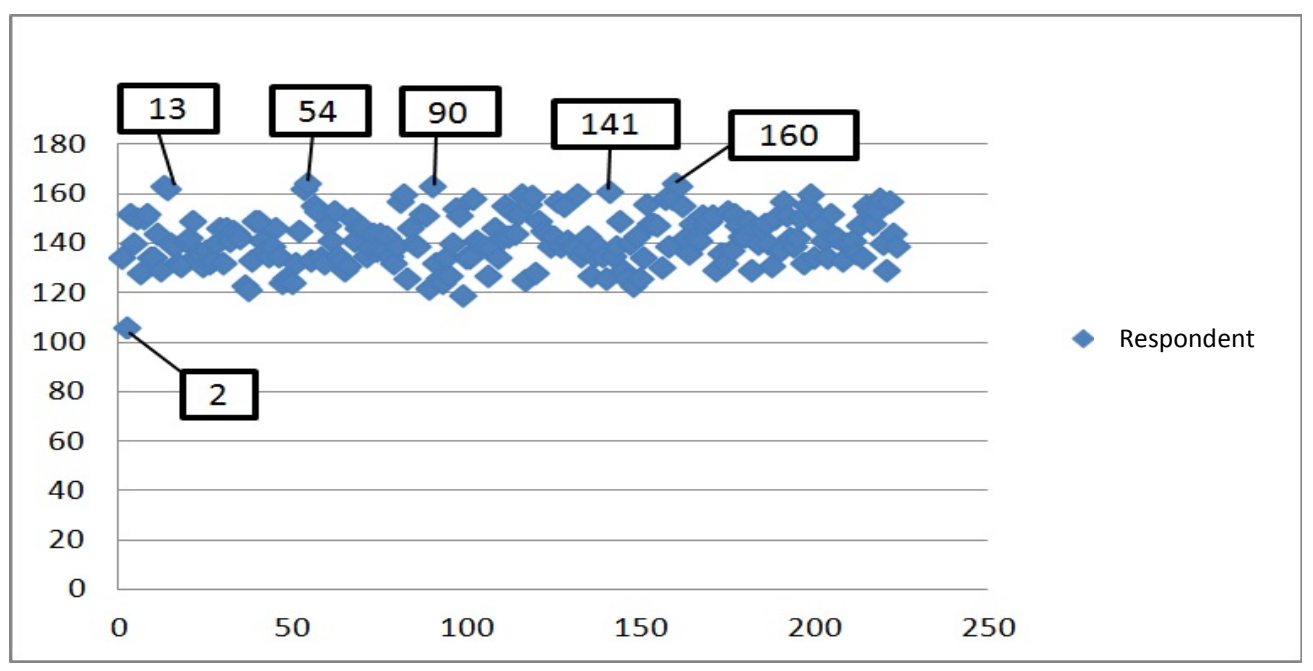

Figure 2.Scatter plot result

Source: Primary Data, analyzed

From Figure 2 it can be seen that the points which are spread far from the group are the outliers. Then, the data were identified by adjusting the number of respondents to the questionnaire, to see whether the outliers who provided the data were willing to be interviewed. From this identification process, six respondents were selected for the interview but only three respondents in the study were willing to be interviewed.

\subsection{Institutional Isomorphism}

Laws and regulations that may be considered as coercive pressures on an organization could be key drivers for the practice of accountability in government institutions. Research conducted by Talbot (2008) also revealed that public officials on managerial levels tend to perceive law to be one of the main drivers of change. As expressed by the respondents:

"Accountability is a mandate of Law No. 25, the derivatives of this are Government regulations, Ministry of Home Affairs regulations, and Ministry of Administrative and Bureaucratic Reform regulations. These regulations are used as the main reference in the preparation of the LAKIP, the determination of key performance indicators, then the strategy, policy, and the program/activity that ends at the output: the outcome." (Maluku Province Public Works Agency).

"Based on the Ministry of Home Affairs regulation, each SKPD is assessed for its performance. The LAKIP is used as one of the indicators to measure the success rate of each SKPD. The SKPD also uses the same reference for the preparation of its LAKIP, by the Decree of the State Administration Institution no. 239/ IX/6/8/2003 and Ministry of Home Affairs Regulation No. 29, 2010." (Department of Cooperatives and SMEs, Ambon City).

"Yes, because of Presidential Instruction No. 7, 1999, we are required to prepare this report." (Department of Forestry, Maluku Province).

DiMaggio and Powell (1983) reported that a mimetic isomorphism emerged as a result of the process to respond to the uncertainty of the environment in the area where the organization operates, so that the organization may make itself just like any other organization.

"For this LAKIP we look for the applicable rules, for the way to prepare it, and so on. Then there is the format of the example, and there are rules, so we follow them." (Department of Forestry, Maluku Province)." 
"We have created this LAKIP. Coincidently there is a reference here that is already clear, namely PERMENPAN No. 53 of 2014 concerning the technical guidelines of performance agreements, performance reporting, procedures for the review of the performance report of government institutions. We made the LAKIP based on the input from each division, and we made it yearly." (Department of Public Works, Maluku Maluku Province)."

Normative pressures, in the context of government institutions, usually come from professional groups such as consultants or universities through conferences, seminars, workshops, training, and mentoring. The role of these professional groups is very crucial for the organization, in order to help it to reduce errors and to improve the chances of success of the practice of accountability (Akbar et al., 2012; Han and Koo, 2010).

"There is a workshop conducted, but I think the reply from the human resources department was, that what we have here is quite right following the allocation. So far, there are no obstacles, because it has been routinely performed each year." (Department of Public Works, Maluku Province)."

"There are meetings conducted by the local governments to synergize, in order to be evaluated, to see if we conform with the rules. Although the actual ability to think, the ability to analyze depends on the level of education, but we are here every day, and make it good already." (Department of Forestry, Maluku Province)."

\section{CONCLUSION}

The results of the quantitative and qualitative analyses showed that the performance of the local government agencies' employees in Maluku and Ambon are influenced by organizational commitment. Moreover, the findings show that organizational commitment can improve the performance of these employees. The positive influence between organizational commitment and the employees' performance is due to their internal and external accountabilities, motivation and level of education.

Results of the analysis in this study found that internal accountability has a positive influence on organizational commitment. This indicates that internal accountability should be perceived by the public sector organizations as a tool to increase their staffs' organizational commitment, which in turn will improve their performance. External accountability does not have a positive influence on organizational commitment. This means that external accountability is seen as a necessity to comply with the applicable rules, but not as a commitment, nor is it able to improve the performance of the employees of government agencies. Job motivation has a positive influence on organizational commitment. Employees who are motivated, with feelings of satisfaction, will commit to staying with their organizations. Education has no positive influence on organizational commitment. This indicates that education is not the main driver for employees of local government agencies to be able to increase their organizational commitment. Furthermore, organizational commitment has a positive effect on performance. This indicates that employees of local government agencies commit to remain in their organization, which will directly impact on the performance generated by them, which will be even better.

The phenomena of isomorphism were also captured in this research which is evident in the results of the qualitative data. Internal and external accountabilities are seen as forms of pressure and coercion, either formally and informally, or as in this case as a coercive isomorphism. The level of education is seen as a form of normative isomorphism. The results from the qualitative data show that what happens in the field is dominated by coercive pressure, 
through LAKIP, which can cause the occurrence of a mimetic isomorphism. Furthermore, the mimetic isomorphism that happens is a consequence of the pressure isomorphism and coercion. It can be said that the phenomenon of the mimetic isomorphism in the Regional Government of Maluku Province is a consequence of the occurrence of the coercive isomorphism.

Results of the study can be used as inputs for local governments into their education programs, in order to improve the performance of the employees of the local government agencies related to internal and external accountability, as well as the individual character of the employees, and their motivation to work, education level and organizational commitment. This is the driving factor organizations can use to improve their accountability and performance so that good governance will occur in the future.

This research also contributes in terms of its methodology, namely by using mixed methods to collect and analyze the data. The use of mixed methods with quantitative approaches and qualitative approaches can explain the deeper phenomena occurring in local government agencies. Finally, this study has practical implications for the actors of public sector organizations, in that public sector organizations need to pay greater attention to the accountability, organizational commitment, job motivation, and educational background of their staff, as all of this makes a significant contribution to improvements in their performance.

\section{LIMITATION AND SUGGESTION}

This study has several limitations. First, the study was only carried out in the departments within the Provincial Government of Maluku and Ambon City Government. Further research can expand the object of the research into other local government agencies. Secondly, the operational accountability variable in this study is limited to internal and external accountability. However, accountability is defined in many dimensions, using different forms of accountability, by such people as Sinclair (1995); Mardiasmo (2009); Romzek and Dubnick (1987); and Ellwood (2003). Therefore, further research can use the dimensions of accountability with performance. Factors used as independent variables that can affect performance are still very limited in number; therefore, further research can explore other factors that can affect the performance of employees of local government institutions.

Third, this study is limited to the factors of individual characteristics, such as motivation and level of education. Future research can include other factors of individual characteristics that influence organizational commitment and performance. Fourth, the lack of respondents willing to be interviewed resulted in a less-thanmaximal qualitative data collection process. However, it is strongly recommended for further research using mixed methods, so it will obtain in-depth information and can capture any isomorphism phenomena that occur in public sector organizations.

\section{REFERENCE}

Akhyaruddin, M. \& Akbar, R. (2016). The relationship between the use of a performance measurement system, organizational factors, accountability, and the performance of public sector organizations. Journal of Indonesian Economy and Business, 31 (1) , 1-22.

Akbar, R., (2011). Performance measurement and accountability in Indonesian local government. Unpublished dissertation, Australia: School of Accounting, Curtin University.

Akbar, R., Pilcher, R., \& Perrin, B. (2012). Performance measurement in Indonesia: the 
case of local government. Pacific Accounting Review, 24(3), 262-291.

Akinyemi, B. O. (2014). Organizational commitment in Nigerian banks: The influence of age, tenure and education. $J$. Mgmt. \& Sustainability, 4, 104.

Allen, N. J., \& Meyer, J. P. (1990). Organizational socialization tactics: A longitudinal analysis of links to newcomers' commitment and role orientation. Academy of management journal, 33(4), 847-858.

Allen, N. J., \& Meyer, J. P. (1997). The measurement and antecedents of affective, continuance and normative commitment to the organization. Journal of occupational psychology, 63(1), 1-18.

As'ad, M. (2008). Industrial psychology fourth edition. Yogyakarta: Liberty.

Ashworth, R., Boyne, G., \& Delbridge, R. (2007). Escape from the iron cage? Organizational change and isomorphic pressures in the public sector. Journal of Public Administration Research and Theory, 19(1), 165-187.

Barclay, D., C. Higgins, \& R. Thompson, (1995). The partial least squares (PLS) approach to causal modelling: Personal computer adoption and use as an illustration. Technology Studies, 2 (2), 285309.

Bang, H., Ross, S., \& Reio Jr, T. G. (2012). From motivation to organizational commitment of volunteers in non-profit sport organizations: The role of job satisfaction. Journal of Management Development, 32(1), 96-112.

Camilleri, E., \& Van Der Heijden, B. I. (2007). Organizational commitment, public service motivation, and performance within the public sector. Public Performance \& Management Review, 31(2), 241-274.

Cascio, W. F. 1998a. Applied psychology in human resource management, $5^{\text {th }}$ Edition. London: Prentice Hall.

Cavalluzzo, K. S., \& Ittner, C. D. (2004). Implementing performance measurement innovations: evidence from government. Accounting, Organizations and Society, 29(3-4), 243-267.
Cetin, M. O. (2006). The relationship between job satisfaction, occupational and organizational commitment of academics. Journal of American Academy of Business, 8(1), 78-88.

Clugston. (2000). Predicting turnover of employees.Journal of Applied Psychology, 24, 132-146.

Creswell, John W. \& Vicki L. Plano Clark. (2011). Designing and conducting mixed methods research. Second Edition. Sage Publication, USA.

DiMaggio, Paul J. \& Walter, W. Powell. (1983). The iron cage revisited: Institutional isomorphism and collective rationality in organizational fields. American Sociological Review, 48, 147-160.

Ellwood, S. (2003). Bridging the GAAP across the UK public sector. Accounting and Business Research, 33(2), 105-121.

Flippo, E.B. (1984). Personnel management. McGraw-Hill, Inc.

Gudono, (2012). Multivariate data analysis. $2^{\text {nd }}$ Edition. Yogyakarta: BPFE.

Han, Joon \& Jasook, Koo. (2010). Institutional isomorphism and decoupling among Korean Firms: Adoption of performance compensation system. Korean Journal of Sociology, 44 (3), 27-44.

Hartman, C.C. (2000). Organizational commitment: Method scale analysis and test of effects. International Journal of Organizational Analysis, 8, 89- 109.

Head of Institute of Public Administration decision, Number 239 / IX / 6/8/2003 on Guidelines for Preparation of Reporting Accountability of Government Performance. (Retrieved, September 2015).

Hood, Christopher. (1991). A public management for all seasons. Public Administration, 6(3), 3-19.

Indonesia Governance Index. (2014, August 7). Performance governance Maluku Province. Retrieved from: http://www.kemitraan.or.id/ govindex/propprofil.php?prop $=30$

Lai, M. C. \& S. L. Fan. (2008). "Use of fit perception in employee behavioral criteria in Taiwan IT industry. Business and Information, 5 (1). 
Mathis, R. L., \& Jackson, J. H. (2006). Human Resources Management, Edisi sepuluh, Penerbit Salemba Empat.

Nugraha, Putri Jefri, (2013). The influence of organizational culture, job satisfaction and leadership style to organizational commitment and employee performance on departement food crops and farm in Pacitan district., Unpublished thesis, postgraduate program. Yogyakarta: UGM.

Nurkhamid, Muh. (2008). Implementation of innovation performance measurement system of government institutions. Jurnal Akuntansi Pemerintah, 3 (1), 45-76.

Presidential Instruction Number 7 of 1999 on Accountability Reporting of the Performance of Government Institutions. (Retrieved, September 2015).

Purnama, N., Sunuharyo, B., \& Prasetya, A. (2016). The effect of motivation of employment to organizational commitment and employee performance. Jurnal Administrasi Bisnis, 40 (2).

Robbins, S.P. \& Timothy A. Judge. (2010). Organizational Behavior (14 ${ }^{\text {th }}$ Edition). Prentice Hall, New Jersey.

Roberts, J., \& Scapens, R. (1985). Accounting systems and systems of accountabilityunderstanding accounting practices in their organisational contexts. Accounting, Organizations and Society, 10(4), 443-456.

Romzek, B. S., \& Dubnick, M. J. (1987). Accountability in the public sector: Lessons from the Challenger tragedy. Public Administration Review,47, 227-238.

Scott, W. R. (1995). Institutions and organizations.

Sholihin, M.,\& Pike. R. (2009). Fairness in performance evaluation and its behavioral consequences. Accounting and Business Research, 39 (4), 397-413.
Sinclair, A. (1995). The chameleon of accountability: forms and discourses. Accounting, Organizations and Society, 20 (2-3), 219-237.

Sofyani, H., \& R. Akbar. (2015). Relationship characteristics of local government employees and implementation of performance measurement systems: Institutional isomorphism perspective. Journal of Accounting and Auditing Indonesia, 19 (2), 153-173.

Spekle, Roland F. \& Frank, H. M. Verbeeten. (2014). The use of performance measurement systems in the public sector: Effects on performance. Management Accounting Research 25, 131-146.

Stanbury, W.T. (2003). Accountability to citizen in the Westminster Model of government: More myth than reality. Fraser Institute Digital Publication, Canada.

Supangat, A. (2007). Statistics in the descripive, inference and nonparametric. First Edition. Jakarta: Kencana Prenada Media Group

Talbot, C. (2008). Performance regimes-The institutional context of performance policies. Intl Journal of Public Administration, 31(14), 1569-1591.

Vinzi, V. E., V., Chin, W.W., Henseler, J., Wang, H. (Eds.). (2010). Handbook of partial least squares: Concepts, methods and applications. Springer Handbooks of Computational Statistics.

Wang, S., Caldwell, S. D., \& Yi, X. (2015). The effects of education and allocentrism on organizational commitment in Chinese companies: A multi-level analysis. International Journal of Manpower, 36(5), 754-771.

Wang, X. (2002). Assessing administrative accountability: Results from a national survey. The American Review of Public Administration, 32(3), 350-370.

Notice: The Journal of Indonesian Economy and Business and its Boards of Editors are not responsible for any errors or flaws found in this article. The authors take full responsibility for their work. 